\title{
Improving firm sustainable performance: the role of market orientation
}

\author{
Christina APPIAH-NIMO \\ Tomas Bata University in Zlin, Zlin, Czech Republic \\ appiah_nimo@utb.cz \\ Miloslava CHOVANCOVÁ \\ Tomas Bata University in Zlin, Zlin, Czech Republic \\ chovancova@utb.cz
}

\begin{abstract}
An outstanding objective of the $U N$ and EU in recent years is to improve the environment in which firms operate. This has increased pressures on companies from consumers, governments, and shareholders alike to develop and implement sustainable business practices. Literature has covered other strategic decisions that will improve a firms' sustainable performance but no study has looked at this from a market-orientation perspective. However, a firm's market orientation is regarded its capability that enables it to identify and respond to customers' desires in order to deliver superior value to them. Other literature has affirmed market orientation as the most critical source of sustainable competitive advantage. Evidently, market-oriented companies can incorporate sustainability activities into their overall business strategies but there is a gap in knowledge as to what extent this affects firm sustainable performance. This conceptual paper, therefore, fills this gap, hence, analysed the impact of market orientation on sustainable performance of firms, and provides an argument on the market orientation to sustainable performance relationship. To achieve this, the study reviewed literature obtained from several databases concerning the related fields. Literature search was conducted using the keywords search via Google scholar engine and other research databases including Scopus and Web of Science. The individual variables were used as key search terms, though a limited amount of information was found, literature on market orientation proved promising. Articles deemed relevant to this conceptual paper were retrieved and reviewed. Additionally, books on the topic were searched using the same key search terms used in the research database. The findings confirmed the relationship between market orientation and firm sustainable performance. Further, it evaluated the mediating and moderating variables that impact the relationship between market orientation and firm sustainable performance. It is recommended that an empirical study is done to prove the strength of the relationships.
\end{abstract}

Keywords: sustainable performance, market orientation.

\section{Introduction}

The sustainability agenda which is way up the list of priorities of the emerging generations (Elkington, 1998) emphasizes committing to incorporate social, environmental, economic (also known as "triple bottom line") and ethical factors into a company's strategic decisions. It subsequently extends to evaluating how these factors affect the business performance, taking into consideration the risks and opportunities these factors present. These factors represent the elements of a new equation to assess and express the value of a business in terms of its sustainability. According to Elkington, the triple bottom line can be viewed as the economic, natural and social capital which a business possesses in its operation, thus, it needs a transformation of mindset and commitment of leadership and firm performance to involve stakeholders (Waddock \& Bodwell, 2007). Engaging in sustainable business will ultimately increase growth and the survival of businesses in this competitive business environment. 
However, the quest to engage and manage sustainability holistically poses a challenge that requires both tangible (people, equipment and technology) and intangible (management capability, culture, and processes) resources to integrate a sustainable culture and strategy that could lead to enhanced business performance (Waggoner, Neely \& Kennerley, 1999). Among these resources, culture and leadership are important intangible resources in achieving sustainable performance (Drucker, 2001). One important internal firm capability to achieving performance is market orientation (MO) (Jaworski \& Kohli, 1993) which is viewed in literature as a behaviour (Kohli \& Jaworski, 1990) and a culture (Narver \& Slater, 1990). In the marketing literature, the concept of market orientation is prominent and viewed as a recurrent theme associated with corporate sustainability (Tollin \& Christensen, 2019). Extant literature (Deshpande, Farley \& Webster, 1993; Kohli \& Jaworski, 1990; Narver \& Slater, 1990) on market orientation conceptualizations although differs in theory, there is, however, an agreement on the influence market orientation has on creating the necessary behaviours and processes which will ultimately develop superior value for consumers through the collection and distribution of market intelligence (Narver \& Slater, 1990). Market orientation is defined as a behaviour of gathering business-wide market intelligence of current and future customer needs, dissemination of such intelligence across all organizational units and how the organization responds to it (Kohli \& Jaworski) while Narver and Slater define it as "the organization-culture that most effectively and efficiently creates the necessary behaviours for the creation of superior value for buyers and, thus continuous superior performance for the business." They characterized market orientation as a three behavioural component: customer orientation, competitor orientation, and inter-functional coordination; and a two decision criteria-long-term focus and profitability.

Customer orientation generally refers to the adequate information of customers which will enable the business to create superior value for them continuously. Thus, customer orientation necessitates a seller's full understanding of the entire value chain of the buyer not only in the present but also in how it will evolve in the future. The second cultural component, competitor orientation refers to the understanding of the strengths, weaknesses, capabilities, and strategies of current and potential competitors. It focuses on how distinctive the competition is (Porter \& Millar, 1985). The final component, inter-functional coordination relates to the utilization of organizational resources to create superior value to the target customer. The seller has the opportunity to create value for the customer at any point in the customer's value chain and also can integrate the various business areas in achieving customer desires through the acquisition of information and sharing among all departments (Porter \& Millar). Hence, creating value for the customer is not a function only for the marketing department but for the whole organization. According to Murray, Gao and Kotabe (2011), market orientation provides the basis of developing the organization's market-based capabilities which facilitate the use and distribution of gathered information to achieve competitive advantage. Extant research also generally supports that market orientation leads to improved firm performance (Davcik \& Sharma, 2016), new product development (Heirati \& O'Cass, 2016) and improved customer value and market effectiveness (Kachouie, Mavondo \& Sands, 2018). Today's consumer assesses products and services they consume based on their product experience (also on how it was made) rather than the product itself. Consumers are now more participative in product development and this has created a need for firms to create business models that are competitively challenging as compared to other firms. Firms now face the challenge of exhibiting best practice strategies to satisfy both internal and external stakeholders. Arguably, in such a rapidly changing environment, firms that are market-oriented are both proactive and responsive to the needs of customers, hence, 
customers who desire a sustainability agenda can be addressed through the adoption of a marketoriented culture which will subsequently increase firms performance.

From the foregoing, a firm's performance increases when market orientation is reinforced due to its ability to meet the changing needs of consumers at any point in the product development process. This conceptual paper, therefore, seeks to investigate whether (i) MO leads to sustainable performance; and (ii) the relationship between MO and sustainable performance is robust across environmental context (Jaworski \& Kohli, 1993).

\section{Literature review}

\section{The natural-resource-based view theory (NRBV)}

Organizations exist and do business in societies that exist in the natural environment. Hence it is now imperative for companies to adopt strategies that are rooted in environmentally sustainable operations. This study is grounded on the natural-resource-based view (NRBV) theory (Hart, 1995) which is an extension of the resource-based view (RBV) theory (Penrose, 1959). Penrose postulates that a firm is not only an administrative unit but also a collection of productive resources and capabilities, where the choice of different uses of these resources over time is determined by administrative decision to achieve firm performance; these resources can also determine a firm's competitive position (Wernerfelt, 1984). Further development of the theory argued that for firms to have a sustainable competitive advantage, the firms' resources must be costly-to-copy, thus, valuable, not- imitable and non-substitutable by competing firms and supported by tacit skills or socially complex organizational processes (Barney, 1991). Resources are explained by extant literature as something a firm possesses which includes both physical and financial assets like human resource skills and organizational processes. In contrast, capability referred to what a firm can achieve based on the available resources. Additionally, these resources and capabilities are rooted in the firm, and their ability to add value may depend on the support of complementary assets and regular practice (Christmann, 2000).

However, Hart extended the RBV to the natural-resource-based view which is made up of three interrelated strategies including pollution prevention, product stewardship and sustainable development which is connected to the achievement of sustained competitive advantage. He argued that the firm is not only made up of the internal capabilities and resources but also the external environment and that "one of the most important drivers of new resource and capability development for firms will be the constraints and challenges posed by the natural (biophysical) environment" (p. 989). Thus, firms will have the challenge of creating strategies to gain competitive advantage rooted in environmental protection and maintenance. This strategy of being environmentally oriented can yield a sustainable competitive advantage. It is evident that different types of resources affect the firms' operations differently, hence it is imperative to note that firms' resources wields a positive effect on the firms' strategic decision to achieve sustainable performance. Firms that are proactive to the environment can evolve overtime to deal with external challenges in the market. However, this theory does not include the stakeholders; the social component of sustainable performance. Hence this study will adopt the stakeholder theory to compliment the NRBV.

\section{Stakeholder theory}

The work of Freeman (1984) on the stakeholder theory led to the global acceptance of theory in management studies. According to Donaldson and Preston (1995), the idea that

corporations have stakeholders has become commonplace in management literature. The 
stakeholder theory challenges financial theories that assert that firms should concentrate only on creating and improving the economic interests of shareholders. Heath and Norman (2004) postulate that several people make a claim on a firm. Therefore, the stakeholder theory addresses the need to balance the claims of shareholders with those of other stakeholders. Post, Preston, and Sachs (2002) define stakeholders as individuals and constituencies that contribute either voluntarily or involuntary to a firm's wealth-creating capacity and activities and are therefore its potential beneficiaries and/or risk bearers. Sweeney (2009) also explains that stakeholders provide subtle resources such as social acceptance as well as more obvious contributions such as capital, labour, and revenue. Halal (2000) also accentuates that these resources are greater than the financial investments of shareholders by roughly a factor of ten.

The risks that confront stakeholders are not only financial in nature but include other employment, quality products and services and environmental challenges. If the firm goes into bankruptcy, employees do not only lose their jobs but also retirement package and health benefits as well, customers also lose what they used to enjoy from the offerings of the firm and livelihoods of residents of the community in which the firm is located, are also affected. These theories are relevant to this study as it highlights how firms can use their internal resources to position themselves in a way which makes them superior to competitors. Market orientation as a culture of a firm can thus be likened to the intangible resource of the firm which explains their unique nature as compared to that of competitors.

\section{Market orientation (MO)}

Market orientation is an organizational philosophy that creates the behaviours necessary for the creation of superior value for consumers which will eventually achieve superior firm performance (Narver \& Slater, 1990). Market orientation is seen as an organizational culture linked to the organization's responses to consumers' needs and wants (Narver \& Slater) and it is posited to be a source of competitive advantage and ultimately enhances performance. If, as the literature suggests, market orientation plays a key role in a firm's profitability, then they need a clear understanding of it in order to implement this philosophy. There are two main complementary perspectives on market orientation: the behavioural (Kohli \& Jaworski, 1990) which posits that market orientation involves the generation of market intelligence on present and future customers, dissemination of such intelligence across organisational units and the organisations' response based on the market intelligence. On the other hand, the cultural perspective connotes customer orientation, competitor orientation and inter-functional coordination (Narver \& Slater). The cultural perspective will be adopted for this study due to the fact that it captures the behavioural aspects proposed by Kohli and Jaworski. A firms' implementation of market orientation refers to the degree to which it is committed to implement the marketing concepts; undertaking marketing research to identify unique customer needs, conducting an audit of the competitive environment to identify their strengths and weaknesses while identifying the opportunities available and integrating their findings into the firms overall strategy to be adopted by every unit in the organisation for coordination of activities.

\section{Firm sustainable performance}

Every firm desires to achieve higher performance at the end of the day. Performance is an inevitable phenomenon that tracks the progress of the interaction and contributions of all the firms' resources and capabilities into achieving firm goals and objectives. This explanation presents performance as a dependent variable. The determinants of firm performance have been 
variously classified depending on the purpose of the study. Sustainability performance generally refers to the holistic consideration of economic, social and environmental progress-adopting a long term focus. Thus, it is the integration of firms' economic, social and environmental objectives into their business strategies and improvement in the balance among all three. The philosophy of sustainability evidently assists firms to reduce risks, avoid waste generation, increase material and energy efficiency, develop new, environmentally friendly products and services and obtain operating permits from local communities (Székely \& Knirsch, 2005). Accordingly, firms that adopt a sustainability strategy become more profitable through persistent activities over the long term.

\section{Methodology}

This conceptual paper is solely based on reviews and analysis of research and data from related literature. Several methods were used to collect and analyze the literature.

Literature search was conducted first using the google scholar search engine. Other research databases used included Scopus, Web of Science (WOS), Proquest and EBSCO. The individual search terms used included market orientation, consequence of market orientation, market orientation and firm performance and sustainable performance. Although a limited amount of information was found on the search term "market orientation and sustainable performance", however, literature on the search term "market orientation and firm performance" proved promising. Most of the literature on "market orientation and firm performance" contained a mediating factor. In general, all other articles deemed relevant to this conceptual paper were retrieved and reviewed.

\section{Data Collection and Data Sources for Future Research}

This conceptual paper is solely based on a review of relevant related literature on the topic. Future research will be a quantitative study where data will be collected through the administration of questionnaire using previously validated instruments that measures the variables (market orientation and firm sustainable performance). Questions for the survey will adopt a Likert scale. The target population would be hotel managers. Issues of ethics will be considered by allowing participants to read and sign a consent form to participate in the study willingly. Participants will also be made aware that information provided in the survey will be completely confidential and used solely for academic purposes.

\section{Results and discussions}

The result of the literature reviewed shows several laudable researches in favour of the impact of market orientation on performance. Arguably, market orientation is a significant catalyst for planning and improving performance in uncertain environment even for small businesses (Didonet, Simmons, Diaz-Villavicencio \& Palmer, 2012). Although extant literature proves there is a relationship between market orientation and firm performance, most of these relationships are either mediated or moderated by one or more environmental factors.

In the context of SME's, Petzold, Barbat, Pons and Zins (2019) found that firms use market orientation strategy in economic crisis, however, they revealed a moderator effect of SME's managers' perception of an economic crisis on market orientation and performance. Additionally, Guo, Kulviwat, Zhu and Wang (2019) confirmed that market orientation is adopted in turbulent and dynamic environment which subsequently leads to high levels of customer 
satisfaction, leading to customer loyalty. That notwithstanding, Sundström and Ahmadi (2019) found no direct relationship between market orientation and firm strategic performance (economic, social and environmental), but they confirmed corporate social responsibility as a mediating factor on the market orientation and social and environmental dimension of the strategic performance but not on the economic element. The obvious reason for this finding was the scope of the study, as it was limited to public housing companies, a sector that is totally unique from other companies in the open market. Furthermore, Ahmadi (2019) examined the moderating effect of external factors on the relationship between market orientation and strategic performance of public housing companies. The results from the study confirmed environmental factors (economic conditions, market and technological turbulence) as a moderating variable in that relationship.

Also, in investigating the relationship between market orientation and brand performance, Iyer, Davari, Zolfagharian and Paswan (2019) found market orientation as a facilitator of specific positioning strategies. They also confirmed these positioning strategies as a mediator between market orientation and brand performance. In order to extend the market orientation philosophy from the firm level to the supply chain, Gligor, Gligor and Maloni (2019) found that a suppliers' market orientation has a direct and positive effect on a firms' profitability and the strength of this relationship increases in a more uncertain and dynamic business environment. Finally, a study of public organizations by Martín-Santana, Cabrera-Suárez and de la Cruz Déniz-Déniz (2020) confirmed market orientation as an enhancer of organizational commitment and ultimately organizational citizen behaviour of employees-going a long way to improve performance. Clearly, market orientation impact on performance has been investigated from several perspectives though mostly on the firm's financial performance (growth and economic activities). It is imperative to conduct studies that investigate the impact of market orientation on economic, social and environmental performance of firms as the activities of every organization impacts on its environment.

\section{Conclusion}

In conclusion, this conceptual paper sought to investigate the relationship between market orientation and firm sustainable performance. Literature reviewed supported the impact of market orientation on performance and the mediating and moderating influence of external and internal business environment on this relationship. Although market orientation is found as a philosophy that is highly related to achieving sustainable competitive advantage of a firm and subsequently, superior performance, its practice in reality among firms is very rare and more needs to be done (Gupta, Sahi \& Chahal, 2013). This may be due to the firm's limited understanding of the market-oriented concept or perceived cost related to gathering information on customers and competitors, dissemination of such information among all units of the firm and recommending and adopting an appropriate strategy to create the customer's value while achieving a competitive edge in the industry.

As rightly pointed out by Avlonitis and Gounaris (1999), firms will only adopt market orientation as a default unless it is necessary for survival and growth. Markedly, market orientation requires an enormous change in firms' philosophy and culture (Deshpande \& Webster, 1989), its structure and processes (Kohli \& Jaworski, 1990), top management or leadership (Jaworski \& Kohli, 1993), and their evaluation of key success factors (Day \& Wensley, 1983, 1988). Hence, the adoption of market orientation is a goal-driven process through the encouragement of firms' culture which is unique from every other organization. And with the 
shift in customer taste and preferences for sustainability, market orientation seems to be the way forward for firms' growth and survival.

\section{Acknowledgement}

This work was supported by the Internal Grant Agency of FaME through TBU in Zlín No.

IGA/FaME/2020/002; Project title: The impact of digital transformation on costumer behaviour and firm's sustainable performance.

\section{References}

Ahmadi, Z. (2019). Moderating effects on the market orientation and strategic performance relationship in public housing. Baltic Journal of Management.

Avlonitis, G. J., \& Gounaris, S. P. (1999). Marketing orientation and its determinants: an empirical analysis. European Journal of Marketing, 33(11/12), 1003-1037.

Barney, J. (1991). Special theory forum the resource-based model of the firm: origins, implications, and prospects. Journal of Management, 17(1), 97-98.

Christmann, P. (2000). Effects of "best practices" of environmental management on cost advantage: The role of complementary assets. Academy of Management Journal, 43(4), 663-680.

Davcik, N. S., \& Sharma, P. (2016). Marketing resources, performance, and competitive advantage: A review and future research directions. Journal of Business Research, 69(12), 5547-5552.

Day, G. S., \& Wensley, R. (1983). Marketing theory with a strategic orientation. Journal of Marketing, 47(4), 79-89.

Day, G. S., \& Wensley, R. (1988). Assessing advantage: a framework for diagnosing competitive superiority. Journal of Marketing, 52(2), 1-20.

Deshpande, R., \& Webster Jr, F. E. (1989). Organizational culture and marketing: defining the research agenda. Journal of Marketing, 53(1), 3-15.

Deshpandé, R., Farley, J. U., \& Webster Jr, F. E. (1993). Corporate culture, customer orientation, and innovativeness in Japanese firms: a quadrad analysis. Journal of Marketing, 57(1), 23-37.

Didonet, S., Simmons, G., Díaz-Villavicencio, G., \& Palmer, M. (2012). The relationship between small business market orientation and environmental uncertainty. Marketing Intelligence \& Planning, 30(7), 757-779.

Donaldson, T., \& Preston, L. E. (1995). The stakeholder theory of the corporation: Concepts, evidence, and implications. Academy of Management Review, 20(1), 65-91.

Drucker, P. (2001). The next society. The economist, 1.

Elkington, J. (1998). Accounting for the triple bottom line. Measuring Business Excellence, 2(3), $18-22$.

Freeman, E. (1984). Strategic Management: A Stakeholder Approach. Boston, MA: Pitman Co

Gligor, D., Gligor, N., \& Maloni, M. (2019). The impact of the supplier's market orientation on the customer market orientation-performance relationship. International Journal of Production Economics, 216, 81-93.

Guo, C., Kulviwat, S., Zhu, J., \& Wang, Y. J. (2019). Competing in an emerging market: antecedents and consequences of market orientation and the role of environmental factors. Journal of Strategic Marketing, 27(3), 248-267.

Gupta, M. C., Sahi, G. K., \& Chahal, H. (2013). Improving market orientation: The theory of constraints-based framework. Journal of Strategic Marketing, 21(4), 305-322.

Halal, W. E. (2000). Corporate community: a theory of the firm uniting profitability and responsibility. Strategy \& Leadership, 28(2), 10-16.

Hart, S. L. (1995). A natural-resource-based view of the firm. Academy of management review, 20(4), 986-1014. 
Heath, J., \& Norman, W. (2004). Stakeholder theory, corporate governance and public management: what can the history of state-run enterprises teach us in the post-Enron era? Journal of Business Ethics, 53(3), 247-265.

Heirati, N., \& O'Cass, A. (2016). Supporting new product commercialization through managerial social ties and market knowledge development in an emerging economy. Asia Pacific Journal of Management, 33(2), 411-433.

Iyer, P., Davari, A., Zolfagharian, M., \& Paswan, A. (2019). Market orientation, positioning strategy and brand performance. Industrial Marketing Management, 81, 16-29.

Jaworski, B. J., \& Kohli, A. K. (1993). Market orientation: antecedents and consequences. Journal of Marketing, 57(3), 53-70.

Kachouie, R., Mavondo, F., \& Sands, S. (2018). Dynamic marketing capabilities view on creating market change. European Journal of Marketing, 52(5/6), 1007-1036.

Kohli, A. K., \& Jaworski, B. J. (1990). Market orientation: the construct, research propositions, and managerial implications. Journal of Marketing, 54(2), 1-18.

Martín-Santana, J. D., Cabrera-Suárez, M. K., \& de la Cruz Déniz-Déniz, M. (2020). Donor Orientation and Employee Attitudes and Behavior in Spanish Blood Transfusion Centers and Services. Applied Research in Quality of Life, 1-25.

Murray, J. Y., Gao, G. Y., \& Kotabe, M. (2011). Market orientation and performance of export ventures: the process through marketing capabilities and competitive advantages. Journal of the Academy of Marketing Science, 39(2), 252-269.

Narver, J. C., \& Slater, S. F. (1990). The effect of a market orientation on business profitability. Journal of Marketing, 54(4), 20-35.

Penrose, E. T. (1959). The Theory of the Growth of the Firm. New York: John Wiley.

Petzold, S., Barbat, V., Pons, F., \& Zins, M. (2019). Impact of responsive and proactive market orientation on SME performance: The moderating role of economic crisis perception. Canadian Journal of Administrative Sciences/Revue Canadienne des Sciences de l'Administration, 36(4), 459-472.

Porter, M. E., \& Millar, V. E. (1985). How information gives you competitive advantage.

Post, J. E., Preston, L. E., \& Sachs, S. (2002). Managing the extended enterprise: The new stakeholder view. California Management Review, 45(1), 6-28.

Sundström, A., \& Ahmadi, Z. (2019). The Mediating Role of CSR on the Market Orientation and Strategic Performance Relationship - A Study of the Public Housing Companies in Sweden. Sustainability, 11(6), 1537.

Sweeney, L. (2009). A study of current practice of corporate social responsibility (CSR) and an examination of the relationship between CSR and financial performance using structural equation modelling (SEM).

Székely, F., \& Knirsch, M. (2005). Responsible leadership and corporate social responsibility: Metrics for sustainable performance. European Management Journal, 23(6), 628-647.

Tollin, K., \& Christensen, L. B. (2019). Sustainability marketing commitment: empirical insights about its drivers at the corporate and functional level of marketing. Journal of Business Ethics, 156(4), 1165-1185.

Waddock, S., \& Bodwell, C. (2007). What is responsibility management? and why bother?. Total Responsibility Management: The Manual, 9-25.

Waggoner, D. B., Neely, A. D., \& Kennerley, M. P. (1999). The forces that shape organisational performance measurement systems: An interdisciplinary review. International Journal of Production Economics, 60, 53-60.

Wernerfelt, B. (1984). A resource-based view of the firm. Strategic Management Journal, 5(2), 171-180. 